\title{
On the street in nineteenth-century London
}

\author{
Colin G Pooley \\ Emeritus Professor of Social and Historical Geography \\ Lancaster Environment Centre \\ Lancaster University \\ Lancaster \\ LA1 4YQ \\ c.pooley@lancaster.ac.uk
}

+44 (0)1524 811606

\begin{abstract}
This paper uses statements made at London's Central Criminal Court (The Old Bailey) by victims and witnesses of crime in nineteenth-century London to reveal the hidden history of pedestrian movement on the city's streets. It demonstrates that men and women of all ages and social groups walked the streets at most times of the day and night, and argues that walking was not only a normal and taken-for-granted activity, but that pedestrianism could contribute to the development of a community of the street.
\end{abstract}

Key words: Walking, Crime, London, Mobility, Pedestrianism.

Word length (Text, tables and references): 8144.

Running head: On the street in nineteenth-century London

Funding: None 


\section{On the street in nineteenth-century London}

\section{Introduction}

The streets of nineteenth-century English cities were crowded places with horses, carriages, omnibuses, trams, pedestrians and (by the late-nineteenth century) bicycles, and a few motor vehicles. This much is evident from literature, photographs and other illustrations. ${ }^{1}$ However, while it is possible to gain at least an inkling of the quantity and use of at least some vehicles through sources such as reports of municipal providers of public transport, ${ }^{2}$ and motor vehicle registrations from the early-twentieth century, ${ }^{3}$ comprehensive information on pedestrians is almost completely lacking. This paper begins to fill this gap by utilising the statements of witnesses to and victims of crime as recorded at London's central criminal court (the Old Bailey) to reconstruct who was on the streets of London in the nineteenth century. These data can never provide more than a partial picture, but they do begin to fill some gaps in the research literature on pedestrians.

Much research on the history of walking tends to be wide-ranging, covering long time periods and/or many geographical areas, often relying on anecdote, and concentrating on walking for leisure and pleasure rather than everyday travel. ${ }^{4}$ Because data on walking is so rarely available all too often

\footnotetext{
${ }^{1}$. See for example the novels of Charles Dickens and George Gissing, or the art of John Atkinson Grimshaw. Academic work that discusses the use of art and literature includes J. Finch, 'Pedestrianism, money and time: mobilities of hurry in George Gissing's The Private Papers of Henry Rycroft', in P G Mackintosh, R. Dennis and D. Holdsworth (eds.), Architectures of Hurry-Mobilities, Cities and Modernity (Abingdon, 2018), 175-193; N. Forgione, 'Everyday life in motion: The art of walking in late-nineteenth-century Paris', The Art Bulletin, 87 (2005), 664-687.

2 . For an overview of the history of British transport see: H.J. Dyos and D. Aldcroft, British Transport: an Economic Survey from the Seventeenth Century to the Twentieth (Leicester, 1969). For a case study see: C. Pooley and J. Turnbull, 'Commuting, transport and urban form: Manchester and Glasgow in the mid-twentieth century', Urban History, 27 (2000), 360-83.

${ }^{3}$ L. Newall, A History of Motor Vehicle Registration in the United Kingdom (Easingwold, third edition 2008).

${ }^{4}$. For instance: J. Amato, On Foot: A History of Walking (New York, 2004); G. Nicholson, The Lost Art of Walking: The History, Science, Philosophy, and Literature of Pedestrianism (New York, 2008): R. Solnit, Wanderlust: A History of Walking (New York, 2001); C. Bryant, A. Burns and P. Readman (eds.), Walking Histories, 1800-1914 (London, 2016).
} 
such research concentrates on the exceptional: those occasions when the experience of walking was most likely to be recorded. More detailed and focused research that does exist mainly examines walking in the twentieth century, when conflicts between pedestrians and motor vehicles came to be perceived as a significant problem leading, in many cases, to the restriction of pedestrian access and to the formation in 1929 in England of The Pedestrians' Association which gave a voice to the increasingly marginalised walker. ${ }^{5}$ David Rooney provides an excellent example of such conflict in his analysis of attempts to segregate pedestrians and traffic through the erection of extensive railings along London's East India Dock road in the 1930s, thus preventing pedestrians crossing the road for long stretches, ${ }^{6}$ a theme also explored by several other authors in Britain and elsewhere. ${ }^{7}$ Other historical research on walking has focused on the extent to which the street was a gendered space, in which female mobility was restricted through a combination of social constraints and perceptions of risk, or on walking as performance focusing often on the role of the flâneur, and frequently drawing on the work of Walter Benjamin. ${ }^{8}$ While valuable, I argue that such research provides only a

${ }^{5}$. Still active as Living Streets: https://www.livingstreets.org.uk/.

${ }^{6}$ D. Rooney 'Keeping pedestrians in their place. Technologies of segregation in East London', in P G Mackintosh, R. Dennis and D Holdsworth (eds.), Architectures of Hurry - Mobilities, Cities and Modernity (Abingdon, 2018), 120-136.

7 . For example: B. Schmucki, 'Against "the Eviction of the Pedestrian" The Pedestrians' Association and Walking Practices in Urban Britain after World War II.' Radical History Review, 2012 (2012), 113138; M. Ishaque and R. Noland, 'Making roads safe for pedestrians or keeping them out of the way?: An historical perspective on pedestrian policies in Britain', The Journal of Transport History, 27 (2006), 115-137; K. Cowman, 'Play streets: women, children and the problem of urban traffic, 19301970', Social History, 42 (2017), 233-256; T. Errázuriz, 'When walking became serious: Reshaping the role of pedestrians in Santiago, 1900-1931', The Journal of Transport History, 32 (2011), 39-65; P. Norton, 'Street rivals: Jaywalking and the invention of the motor age street', Technology and Culture, 48 (2007), 331-359; P. Norton, 'Urban mobility without wheels: a historiographical review of pedestrianism', in G. Mom, G. Pirie and C. Tissot (eds.), Mobility in History: the State of the Art in the History of Transport, Traffic and Mobility (Neuchâtel, 2009), 111-115; P Norton, Fighting Traffic: the Dawn of the Motor Age in the American City (Boston, MA, 2011).

${ }^{8}$. G. Gilloch, Myth and Metropolis: Walter Benjamin and the City (Cambridge, 1996); C. Jenks 'Watching your step: the history and practice of the flâneur', in C. Jenks (ed.), Visual Culture (London, 1995), 142-160; J. Guldi, 'The history of walking and the digital turn: stride and lounge in London, 1808-1851', The Journal of Modern History, 84 (2012), 116-144; P. Parkhurst Ferguson, 'The flâneur on and off the streets of Paris', in K. Tester (ed.), The Flaneur (London, 1994), 22-42. 
very partial view of walking in the past, ignoring the vast array of pedestrian journeys that were undertaken every day to fulfil mundane tasks such as travel for work, to shop and for other errands, or to visit friends. It is such travel that this paper seeks to uncover.

The paper has two main aims: first to describe who walked the streets of London at different times of day and for different purposes; and, second, to interpret these data in the context of nineteenthcentury urban society. Within this framework it is possible to explore variations by gender, occupational group and (to a limited extent) age. The paper argues that in nineteenth-century London the streets provided an environment that could be accessed by most people, and that men and women of all ages and social groups were present on the streets of the city thus creating a culture in which walking was the normal and taken-for-granted means of moving around the urban area. The data do not provide answers to all the questions that could be asked, and they do contain biases which are outlined below. However, this analysis does provide a fuller picture of the varied nature of the pedestrians who walked the streets of London than any other source so far analysed. The streets of other British cities were probably similar, though this cannot be assessed here.

\section{The data}

The records of London's central criminal court (the Old Bailey) provide detailed transcripts of the court proceedings, including statements by victims, witnesses and those accused, and examinations by magistrates. For the period 1674-1913 these data are available in a searchable form through the Old Bailey on-line service. ${ }^{9}$ These data have been extensively mined for research on crime, criminality, sentencing and related issues, ${ }^{10}$ but the statements do also have the potential to be used for other purposes. ${ }^{11}$ Much of the crime that came to the Old Bailey had been committed on the street and in other public places (for instance pickpocketing, assault and other crimes against the person), and in such cases the statements made in court also provide a record of who was present when a crime was committed. For the purposes of this paper I have sampled the Old Bailey records from 1801 to 1911, taking one complete year from each decade. To enable easier comparison with other demographic data the sampled years coincide with a census year (i.e. 1801, 18111821 etc). For each of these 12 years I searched for the term walk/walking and this produced a sample of 1,785

\footnotetext{
${ }^{9}$. Old Bailey on-line: https://www.oldbaileyonline.org/forms/formMain.jsp.

${ }^{10}$. The related website, the digital panopticon, provides a full introduction to the Old Bailey records, including analysis and references on a wide range of topics related to crime and justice:

https://www.digitalpanopticon.org/.

${ }^{11}$. See for example Peter Andersson's study of pickpocketing in Victorian London which does shed some light on pedestrian behaviour: P. Andersson, "'Bustling, crowding, and pushing": pickpockets and the nineteenthcentury street crowd', Urban History, 41 (2014), 291-310.
} 
offences where walking was directly referred to, sometimes multiple times. This represented 10.3 per cent of all offences recorded in the Old Bailey database for the selected years. Undoubtedly other offences did contain statements from people who walked, but these are difficult to identify. Statements for all the sampled offences were read and data extracted for all those statements by victims and witnesses where the individual was walking on the street and also provided some additional information. Statements by the accused were rarely recorded unless it was obvious that they were walking as part of their normal routine, rather than with the purpose of committing a crime. Statements by police on duty on the street were also not routinely recorded except to provide selected examples of the extent of police presence and their role as a witness. In total this provided information from 539 individuals for whom relevant text was recorded and summary statistics entered into a database. ${ }^{12}$ These data provide a rich source of information about pedestrians on the streets of London during the nineteenth century.

There are, of course, limitations to the data and biases created by the nature of the source. Data on an individual's gender, whether the person was an adult or a child and on the number of companions were present in all cases. Time of day was indicated with sufficient clarity to classify this as morning, afternoon, evening or night in 89.2 per cent of cases (with a further 5.6 per cent identifiable as daytime rather than evening or night), and walking purpose was either stated or could be inferred in 70.3 per cent of instances. Sufficient information to make a simple occupational classification was provided in $\mathbf{5 6 . 6}$ per cent of statements, but precise age was never mentioned by adult informants. Some locational data are usually given, ${ }^{13}$ but there is rarely sufficient information to deduce the distance walked. Recorded offences were quite evenly spread across different seasons of the year, ${ }^{14}$ and the characteristics of those making statements changed little over the century. For the purposes of this paper the statistics used are aggregated for the whole time period to provide a better sample size.

Clearly the data only record information on those who happened to either be a witness to or a victim of a crime that led to an arrest and prosecution at the Old Bailey and thus most cases come from the old city rather than from expanding suburbs. This fact may also lead to three further biases. First, it is likely that more street crime occurred in the evening and at night than during the daytime, and thus it can be suggested that the statements of both victims and witnesses will be biased towards those who were on the streets at the times when crimes occurred. Two other biases relate only to

\footnotetext{
${ }^{12}$. These represent 30.1 per cent of the data initially sampled.

${ }^{13}$. Spatial analysis of the data is not undertaken in this paper.

${ }^{14}$. Month by month variation is also affected by when cases were heard at the Old Bailey.
} 
victims. It seems probable that those walking alone may have been more vulnerable to crime against the person than those walking with companions, and that a pickpocket would most likely target pedestrians who appeared to have possessions worth stealing: most commonly a handkerchief, money or a watch. ${ }^{15}$ Victims may thus be biased towards those who appeared to have more means. The validity of these assumptions can to some degree be tested by comparing the characteristics of victims and witnesses: while victims may have been targeted, witnesses should be a random crosssection of those on the streets at a given time of day. Although 65.3 per cent of all witnesses were walking alone this figure rose to 73.8 per cent for victims of crime suggesting that there was indeed a small tendency for solo travellers to be over-represented in the data. However, there was only a relatively small difference between witnesses and victims with regard to social group: 48.2 per cent of witnesses (where occupation was stated) were in the two highest occupational categories and 53.9 per cent of victims. ${ }^{16}$ It is the case today that males are more likely to be targets of crime than females, ${ }^{17}$ and the same was true in the past. In these data 57.5 per cent of men who made statements had been victims of crime but only 49.1 per cent of women. However, with the above exceptions the characteristics of victims and witnesses were largely similar.

The fact that all the pedestrians recorded for this study encountered a street crime (either as victim or witness) could give the impression that walking the pavements of London was particularly dangerous. However, this is unlikely to have been the case. Crime rates in the nineteenth century were relatively low, and for the most part fell over the century. ${ }^{18}$ The court records do not of course give any indication of who was on the street but did not encounter a crime, and there are no other comprehensive sources that could provide this information. However, for a different project I have been studying a large number of nineteenth and early-twentieth century diaries for the purposes of examining all forms of everyday mobility. In these diaries travel on foot occurs frequently but only one incident of pickpocketing (at a railway station in mid-nineteenth century London) was recorded. The vast majority of travel on foot (and by other means) was unproblematic. ${ }^{19}$ In the following

\footnotetext{
${ }^{15}$. See for instance: D. Jones, Crime, Protest, Community and Police in Nineteenth-Century Britain (London, 1982); C. Emsley, Crime and Society in England, 1750-1900 (London, 2010); P. Andersson, Street Life in Late Victorian London: the Constable and the Crowd (Basingstoke, 2013).

${ }^{16}$. A simple four category classification of occupations was used. Details are given in table 1.

17 . S. Smith, Crime, Space and Society (Cambridge, 1986).

18 . Emsley, Crime and Society; Jones, Crime, protest, community and police.

${ }^{19}$. Some 50 diaries from $\mathrm{c} 1800$ to 1960 have been studied in detail. More information about this research can be found in: C. Pooley, 'Cities, spaces and movement: everyday experiences of urban
} 
sections the characteristics and experiences of London pedestrians are explored and set within a broader social and cultural context.

\section{Who was on the street?}

Bearing in mind the caveats outlined above, the data can be used to provide one view of who walked the streets of nineteenth-century London. Table 1 summarises this information for the entire period as there was little variation between sample years. Overall some 80 per cent of those giving statements as victims or witnesses were male and over 90 per cent were classified (by me) as adult. ${ }^{20}$ Pedestrians who gave statements were quite evenly distributed between the four occupational categories used in the analysis, with those in low or unskilled occupations the least likely to appear as a witness or victim. However, in 43.4 per cent of cases no occupational data were available. Over 40 per cent of those giving statements at the Old Bailey were walking the streets in the evening and over 50 per cent of walking activity classified as for leisure activities. These two characteristics are obviously related as most daytime walking would be most likely to occur for workrelate purposes. Almost 70 per cent of pedestrians who gave statements were walking alone and almost a quarter had just one companion. Walking in large groups was rare. To summarise, what these data show is that although men dominated the streets a substantial minority of pedestrians were female; that people of all occupational classes walked the streets of London; that most people walked alone for at least some of their journeys, and that the streets were busy with pedestrians in the evening and also late into the night.

\section{Table 1 here.}

Comparison of male and female pedestrians (Table 2) shows only small differences in the characteristics of men and women who walked London's streets (and who gave statements at the Old Bailey). More men walked alone than did women, but over half of all female pedestrians were alone on the street. Walking in the evening and walking for leisure were overwhelmingly the most common characteristics for both men and women, though women were more likely than men to walk in the afternoon and men were more likely to walk in the morning and at night. For men travel for work was the second most important reason for walking, and this was also the case for women if

travel in England c1840-1940', Urban History, 44 (2017), 91-109; C. Pooley, 'Travelling through the city: using life writing to explore individual experiences of urban travel c1840-1940', Mobilities, 12 (2017), 598-609.

${ }^{20}$. Minors usually stated their age in their statement but this classification is to some extent arbitrary as otherwise age was not given. 
journeys classed as 'errands' are viewed as normal female work related to home and house care. Where identifiable such journeys were all associated with unpaid female labour of some kind. Occupations were only available for 56.6 per cent of those giving evidence (and for only 19.8 per cent of women) so data on variations in the characteristics of pedestrians by occupational class must be interpreted with care due to some small numbers (Table 3). Overall, differences between occupational categories are small. Those in professional and non-manual occupations were most likely to be on the streets in the morning (possible because some had more flexible working patterns), but for all classes most recorded pedestrian activity occurred in the evening. Those in skilled manual work were most likely to be walking at night. More than 70 per cent of walkers in all occupational groups travelled alone, with those in low-skilled work least likely to be with a companion. Travel for leisure was the most important category in all occupational classes, but with those in skilled manual occupations most likely to be undertaking leisure travel. Travel for work was most common for both those in professional work and for the low skilled. In summary, the population that travelled the streets of London during the nineteenth century was clearly diverse, was drawn from all groups within society, and travelled for a wide variety of reasons at all times of the day and night. There are some consistent patterns in the data (for instance the predominance of evening leisure walking), but these may relate primarily to the nature of the data which reflect when street crime was most likely to occur.

\section{Table 2 here}

\section{Table 3 here}

\section{Individual testimonies}

While the aggregate analysis presented above can provide a useful overview of the characteristics and diversity of pedestrians in nineteenth-century London, the detailed individual statements from witnesses and victims provide much more informative insights into the nature and experience of pedestrian travel. This section draws selectively on these qualitative data. In any analysis of text there will always be issues of selection bias. The statements of witnesses and victims provide a rich source and just those portions selected and recorded for this research amount to some 60,000 words. These have all been read carefully and those quotes used have been selected to be representative of the diverse range of walking experiences recorded. In the following section I use these testimonies to explore in more detail the characteristics of those on the street in nineteenthcentury London, when they walked and their reasons for travelling. 


\section{Why people walked}

Travel to and from a workplace, or in the course of employment, was a regular part of the lives of most men and some women, though such journeys are probably under-represented in the Old Bailey data as they occurred at times and in places where crime was less likely than it was for leisure trips. Frederick Austin and Robert Burns (quoted below) were both ordinary working men undertaking a routine journey to or from work when they encountered crime (one as a witness and one as victim). Such journeys were commonplace and would have formed a large part of the daytime pedestrian activity in London or any large city.

I am a bricklayer, and live at 3, Eaton-place, Princes-terrace, Regent's-park. On 30th May, I was going to my work, and met Miss Vaughan-before I met her, I met six young chaps running round the corner from the Queen's-road-they were running from the direction of Miss Vaughan, coming from the Queen's-road, towards Princes-terrace, and they turned down by the corner of a public-house ${ }^{21}$

On the following Tuesday, the 30th, I left work at 10.30 p.m., and met the prisoner in Abbot Road about 800 or 900 yards from the works - I was on my way home; we were passing each other-he said, "Now you b-bastard" - I was walking rather sharp; when I had got on about two paces I looked round, and saw him pointing a revolver at the upper part of my body. ${ }^{22}$

Women also walked at all times of the day both for paid employment and as part of their many unpaid household duties which included shopping and other necessary tasks. Ellen Madden was walking with a friend on her way home from work in the evening when she was the victim of an assault, and Elizabeth Fox was returning alone from an errand to buy ribbon when she was robbed. Both examples are typical of the many everyday walking trips that women in nineteenth-century London undertook:

I live at 8, Half Moon Court, Portpool Lane-on November 2nd, about 6 p.m., I had just left off work, and was walking up Holborn with a friend-the prisoner came out of a publichouse with a friend, with a jug in her hand-her friend took the jug from her-the prisoner

\footnotetext{
${ }^{21}$. Witness statement by Frederick Austin, $8^{\text {th }}$ July 1861. Old Bailey (OB) Ref: t18610708-544.

${ }^{22}$. Victim statement by Robert Burn, $12^{\text {th }}$ January 1891. OB Ref: t18910112-154.
} 
followed me and called me bad names, and struck me on my eye with a knife, and a second blow across my right ear. ${ }^{23}$

I am a widow, and live in Gloster-terrace, Mile End-road. On the 24th of September, at six o'clock in the evening, I was in Whitechapel - I had been to buy some ribbon, and returning about seven o'clock, the prisoner was standing at the corner of Mr. Mears's, the bell founder .$^{24}$

Children were also often used for household errands, or to assist with mundane aspects of female work. In these ways women could combine their duties (paid or unpaid) with child care. It was not uncommon for quite young children to be walking the streets in nineteenth-century London, although they featured relatively rarely as either victims or witnesses of crime. ${ }^{25}$ The experience of James and Eliza Hall, sent on a work-related errand by their mother, was not atypical:

I am the wife Thomas Hall , we live at No. 14, Great Ormond-yard, Great Ormond-street, I am a laundress. On Friday last I was employed to iron four shirts, they belonged to Mr. Waterfield. I sent them home by two of my children; James Hall was one of them, he is six years old; his sister, Eliza Hall, was with him, she is eight years old. I sent them home with them about seven o'clock in the evening, they were to go to Brunswick-row, Queen-square; I heard that the shirts were lost. ${ }^{26}$

Although for much of the nineteenth century school attendance was highly variable ${ }^{27}$ it was completely normal for those children who did attend a school to walk unaccompanied by an adult: sometimes with friends and sometimes alone. Inevitably, on occasion, the children encountered some form of criminal behaviour. Robert Worth and Annie Edgely are typical examples: both children walked alone and the statements given also indicate the sort of distances that children might travel locally from home to school:

I was going home from school, it was about a quarter past twelve I go to school at Mr. Parry's, by Hackney turnpike, I had my watch with me then in my waistcoat pocket, I put the

\footnotetext{
${ }^{23}$. Victim statement by Ellen Madden, $16^{\text {th }}$ November 1891. OB Ref: t18911116-34.

${ }^{24}$. Victim statement by Elizabeth Fox, $24^{\text {th }}$ October 1821. OB Ref: t18211024-53.

${ }^{25}$. Children or youths formed only 6.7 per cent of the statements recorded.

${ }^{26}$. Victim statement by Ann Hall on behalf of her two chidren who were robbed in the street, $3^{\text {rd }}$ April 1811. OB Ref: t18110403-87.

${ }^{27}$. H. Silver, A Social History of Education in England (London, 1973).
} 
chain through my waistcoat button hole.... Q. Whereabouts was it that anything happened to you. - A. Almost facing of the Nag's Head, about a quarter of a mile from the school, and about half a mile from my father's house. I was in the road walking towards my father's. Three men came all of a row, they met me. ${ }^{28}$

I live at 46, Gurley Street, New Kent Road-I have a daughter named Annie Gertrude, who was six years old on Monday-she left home to go to school, six minutes' walk off, and at 10.30 I met a policeman with her outside my house-I do not know the prisoner. ${ }^{29}$

Although it is likely that most everyday journeys covered familiar territory, such as the travel to work or school outlined above, on occasion people needed to walk to unfamiliar destinations. Elizabeth Pickard had reason (unspecified) to go from her home to Gray's Inn Road, a distance of some three kilometres (two miles). She was unsure of the way, asked directions and was led the wrong way and then robbed. While most such journeys were almost certainly unproblematic this example does demonstrate clearly that when necessary women walked alone to neighbourhoods with which they were unfamiliar:

I am the wife of Henry Pickard, of 75, Devon-shire-street, Lisson-grove-he is a horseBreaker-about 5 o'clock in the afternoon of 20th May, I was in Great Queen-street, and saw the prisoner there-I asked him to direct me to Gray's Inn-road-I took out my purse and gave him the direction which I had in it-he told me he knew where it was well, he would show me, and as he read the direction he passed a little way to show me-instead of showing me the right direction he took me quite the reverse-he walked with me, I should say, about five minutes, and then snatched my purse from my hand ... (OB Ref: t18610610474)..$^{30}$

The distances over which people walked are rarely recorded, but the implication from most statements is that they were over relatively modest distances within a few kilometres of home. However, some men tramped the streets for long periods when unemployed and looking for walk. For instance David Kenrick stated that he had been walking all day when he was charged with (and found guilty of) breaking and entering a warehouse which he had stopped for a rest:

\footnotetext{
${ }^{28}$. Victim statement by Robert Worth (age 9), 30 $0^{\text {th }}$ October 1811. OB Ref: t18111030-46.

${ }^{29}$. Victim statement by Patrick Edgely on behalf of his daughter Annie (age 6), $4^{\text {th }}$ May 1891. OB Ref: t18910504-441.

${ }^{30}$. Victim statement by Elizabeth Pickard, $10^{\text {th }}$ June1861. OB Ref:t18610610-474.
} 
I had been walking about all day looking for work; so after I looked for work up to 7 o'clock, I walked round, and being without lodging, and knowing the firm through working there, I got over the wall. ${ }^{31}$

By far the commonest reason given for walking the streets of London (where journey purpose was stated or could reasonably be implied) was for leisure activities, especially in the evening. This was true of both men and women and people from all occupational backgrounds. In many cases a victim stated that they had been drinking alcohol which may have contributed to their vulnerability. This may have been the case for Samuel Cooper, a labourer who endured an attempted robbery while walking home after an evening drinking. At the other end of the social scale William Lewers was a barrister who had been dining with friends at a smart hotel beside the river Thames at Greenwich and was robbed while taking the short walk back to the nearest station to travel home. There is no specific mention of intoxication on this occasion but no doubt the companions had dined well. This example also reminds us that for longer journeys, especially for those who could afford to use public transport, walking was often part of a multi-mode trip.

I am a labourer, and live at No. 9, Duke-street, Commercial-road. On Saturday night, the 1st of January, I was returning home through Wentworth-street, Spitalfields ; I was a little in liquor... ${ }^{32}$

I am a Barrister, and have chambers at 3, Brick-court, Temple-on Saturday, 11th May, I had been dining at the Trafalgar, at Greenwich, along with other members of the Durham Sessions, and Between half-past 10 and 11 o'clock I was returning with my friends to the station-when we got near the railings of the College the prisoner and another man came up-I was walking with my friend Mr. Shield - the prisoner caught at my watch-chain, and it immediately went $-{ }^{33}$

Victorian London had a thriving night-time economy with plentiful opportunities to drink in pubs, beer houses and cafes at most times of the night and, consequently, the streets of London were rarely empty of pedestrians. ${ }^{34}$ The example of Henry Turner (below) shows how an apparently

\footnotetext{
${ }^{31}$. Prisoner's statement by David Kenrick, $24^{\text {th }}$ June 1901. OB Ref: t19010624-478.

32 . Victim statement by Samuel Cooper, $6^{\text {th }}$ January 1831. OB Ref: t18310106-146.

${ }^{33}$. Victim statement by William Lewers, $10^{\text {th }}$ June 1861 . OB Ref: t18610610-518.

${ }^{34}$. B. Harrison, Drink and The Victorians: The Temperance Question in England 1815-1872 (Keele, 1994); J. Greenaway, Drink and British Politics since 1830: a Study in Policy-Making (Basingstoke,
} 
respectable tradesman could move from routine travel home by bus to walking and drinking (though he claims not to excess) with friends and eventually falling prey to crime in the early hours of the morning. Women were also present on London's streets at night, some working as prostitutes procuring men (such as Elizabeth Collins cited below), but many others were simply out enjoying night-time entertainment with friends as appeared to be the case for Ellen Fairway who was witness to a night-time assault:

I am a journeyman Butcher, and live at Hoxton Old Town-on Saturday, 19th May, I was working at Brixton-hill-I was returning home from my employment that evening-I came to London-Bridge on the' Bus-I there met a friend of mine, a Baker, and we went to his Brother's, at Dock head-I remained there till about 1 in the morning-we had something to drink there, but I was as sober as I am now-on my way from Dock head to London-Bridge I met a female, and went with her to a public-house... ${ }^{35}$

I live at 26, Brunswick Street-I have been living with, the prisoner for some years-I have been getting my living as an unfortunate walking the Strand and Fleet Street .... ${ }^{36}$

I am single, and live in Giffin-street, Deptford. I get my living by shirt-making-I was walking in High-street, between twelve and one o'clock, on the night in question, and saw Welsh walking just before me-I saw the prisoner come behind her and kick her... ${ }^{37}$

Finally, in this section exploring the varied reasons why people walked the streets of London at different times of the day and night, it is important to emphasise that not all leisure activity involved late-night drinking and associated activities. When Mary Mahoney encountered crime she was simply visiting her father's house on a rare evening off work, undertaking what would have been a routine 30 minute walk:

I am single, and live with Mr. Allman, in Upper Stamford-street; my father lives in Bondcourt, John-street, Commercial-road. On Sunday night, the 12th of September, my mistress

2003); J. Nicholls, The Politics of Alcohol: a History of the Drink Question in England (Manchester, 2009).

${ }^{35}$. Victim statement by Henry Turner, $10^{\text {th }}$ June 1861. OB Ref: $\mathrm{t} 18610610-527$.

${ }^{36}$. Victim statement by Elizabeth Collins, $6^{\text {th }}$ April 1891. OB Ref: t18910406-379.

${ }^{37}$. Witness statement by Ellen Fairway, $12^{\text {th }}$ May 1851 . OB Ref: $t 18510512-1204$ 
gave me leave to go home-I left about eight o'clock, and met my sister Margaret and George Lartin, and went with them towards my father's house .... ${ }^{38}$

\section{Companions on the street}

While walking for leisure was often a sociable activity, undertaken with friends or relatives, utility walking undertaken to perform routine everyday tasks was more often undertaken alone. Also, at the end of an evening out a final journey home could be unaccompanied and, as shown above, a majority of walking trips recorded in the witness and victim statements by both men and women were carried out without companions. Ann Pulham was walking alone, after dark, in an area some two kilometres from her home. The journey purpose is not stated but she was clearly a respectable woman for whom travelling unaccompanied in London some distance from where she lived was quite normal. Similarly, Elizabeth Sanderson, who worked as a servant, appeared to be undertaking a routine journey home on her own when she witnessed a crime. Walking alone was also normal for people who could clearly afford to use public transport if they wished: Rees Price (a surgeon) walked alone some three kilometres (two miles) from his home on what would have been a dark September evening.

I am single, and live at 18, De Beauvoir terrace, De Beauvoir-town, and am a telegraphic clerk-about 6 o'clock on the evening of the 12th January I was walking in Shoreditch-it was rather dark - I was attacked by three persons - the prisoner was among them - they caught hold of my bag, and pulled me a little way up a court, and when the prisoner found I did not leave hold of my bag he struck me on the cheek ... Cross-examined by MR. COOPER. Q. You say it was rather dark? A. Yes-I had my veil down-this was at the corner of Eyre'salley-it was all done in the course of half a minute-I was very much alarmed and frightened. ${ }^{39}$

I am servant to Joseph Albert, a butcher, in, Arawell-street. About nine o'clock, on the 15th of April, I was coming home, and saw Robertson walking to and fro near the shop-I watched him, saw him make two or three attempts, and at last take a piece of beef off the block .... ${ }^{40}$

\footnotetext{
38 Victim statement by Mary Mahoney, $29^{\text {th }}$ November 1841 . OB Ref: t18411129-282.

39 . Victim statement by Ann Pulham, $28^{\text {th }}$ January 1861. OB Ref: t18610128-162.

${ }^{40}$. Witness statement by Elizabeth Sanderson, $10^{\text {th }}$ May 1841 . OB Ref: t18410510-1371.
} 
I am a surgeon, and live in Cannon-street, City. On the 24th of July between eight and nine o'clock at night I was walking down the Commercial-road, holding up my umbrella, as it rained hard; the prisoner suddenly presented himself before me, so as to stop me ... ${ }^{41}$

Both women and men also travelled with companions for a variety of purposes during the day, through the evening and well into the night. Men, women and children often, of course, walked together as a family, but small groups of men and women could also be found on the streets especially in the evenings. The testimonies of Sarah Clark, Dennis Humbert and Albert Evans provide some typical examples:

I am single, and am a crape collar-maker. On Thursday, 16th Jan., I was walking with my sister along the Whitmore-road, Shoreditch-I had a parcel in my hand, containing eighteen crape collars and a pair of sleeves-a person came behind, put his hand over my shoulder, snatched the parcel, and ran away .... ${ }^{42}$

I am a coal-merchant . On the 26th of August, about a quarter past nine o'clock at night, I was at the corner of Neptune-street, Ratcliffe-highway, walking with a lady, my daughter and another lady were behind, and behind them my son. Just as I got round the corner into Wellclose-square , I saw three boys apparently at play .... ${ }^{43}$

I am a porter, of 3, New Court, Spitalfields-on 25th November, about midnight, I was walking in Wheeler Street, with three persons-I bade them good night, and a man from behind put his hand into my trousers pockets, which were empty. ${ }^{44}$

Even when people walked without companions they would rarely be alone on the street. It is clear from witness and victim statements that the streets of London were full of people at almost all times of the day and night, with frequent references to a crowd gathering or obstructing a path. Although a mass of people could provide cover for crimes of theft from the person, the presence of others on the street could also have been reassuring. It was often the case that an incidence of pickpocketing was noticed by another pedestrian before the item was missed by the victim, with the witness helping to identify and apprehend the perpetrator of the theft. The following statements all make

\footnotetext{
${ }^{41}$. Victim statement by Rees Price, $12^{\text {th }}$ September 1821 . OB Ref: t18210912-88.

${ }^{42}$. Victim statement of Sarah Clark, $3^{\text {rd }}$ February 1851. OB Ref: t18510203-495.

${ }^{43}$. Victim statement of Dennis Humbert, $12^{\text {th }}$ September 1821 . OB Ref: t18210912-188.

${ }^{44}$. Victim statement of Albert Evans, $14^{\text {th }}$ December 1891. OB Ref: t18911214-124.
} 
explicit reference to the crowds on the street while in some cases also providing examples of assistance from street companions previously not known to the victim.

I live with Mr. Weakley, and was with him - there was a crowd, and Mr. Weakley got a-head of me; I saw the prisoner putting a handkerchief under his coat, which I thought was Mr. Weakley's - I told him, and he took it from him. ${ }^{45}$

I live in Furnival's Inn, and am a solicitor. On the 9th of November, about three o'clock in the afternoon, I was in Cheapside : my gold pin, set with pearls was in my stock; there was a very great crowd - I was walking in the middle of the road, to avoid the crowd .... ${ }^{46}$

I have a literary occupation, and live in John-street, Bedford-row. On 10th Nov. I was walking from St. Paul's Churchyard to Farringdon-street-I arrived at the corner of Ludgate-hill, but was not in Farringdon-street-the crowd pressed against me-there was a lady with me, who was parted from me by the crowd, and we were trying to get through singly ..... ${ }^{47}$

I am a miniature-painter, and live in Regent-street. On the evening of the 1st of July I was walking in Argyle-place, a little before eight o'clock - I heard a cry of Stop thief! and saw Hobbs running after the prisoner; I had felt my coat pocket moving, and missed my handkerchief, which I had safe the minure before - I afterwards received it from a gentleman who saw it on the ground, and ran after me with it. ${ }^{48}$

In addition to other pedestrians going about their everyday business, it is also clear from statements made at the Old Bailey that police constables were highly visible on the street and were able to attend scenes of crime very quickly and effectively. ${ }^{49}$ These were also supplemented by watchmen employed to patrol particular buildings. Presumably, such official presences on the streets provided reassurance to many, and reinforced the perception that the streets of London were mostly safe for men, women and children to traverse on foot at most times of the day and night. The following

\footnotetext{
${ }^{45}$. Witness statement by Henry Stabb, $1^{\text {st }}$ December 1831. OB Ref: t18311201-82.

${ }^{46}$. Victim statement by James Gadsden, $1^{\text {st }}$ December 1831. OB Ref: t18311201-130.

47 . Victim statement by John Oxenford, $24^{\text {th }}$ November 1851 . OB Ref: t18511124-32.

${ }^{48}$. Victim statement by Simon Rochard, 30 ${ }^{\text {th }}$ June 1831. OB Ref: t18310630-338.

49 . P. Smith, Policing Victorian London: Political Policing, Public Order, and the London Metropolitan Police (Westport Conn. , 1985); Andersson, Street Life; V. Bailey (ed.), Policing and Punishment in Nineteenth Century Britain (London, 2015).
} 
statement by a police constable is typical and shows the level of police surveillance that existed on many London streets.

On January 27th, in the early morning, I was on duty in Commercial Street, and saw some men on the footpath, and the prosecutor walking on-I slipped into a doorway and saw the prisoner go behind him and hit him on the back of his head-he fell, and two prisoner kicked him, and some other man attacked him - I took the prisoner. ${ }^{50}$

\section{Conclusions}

Almost all historical research is to some extent constrained by the sources available. It is important to stress that the data collected from the statements made at the Old Bailey are not a complete or unbiased record of who walked the streets of London in the nineteenth century. They refer only to those people who either observed or were the victims of a crime where an arrest was made and which was subsequently tried at London's Central Criminal Court. Some of the likely biases were outlined above, and these must be borne in mind when interpreting the data. However, I argue that despite such limitations the data do provide one informative view of the diversity of people who travelled on foot in nineteenth-century London, and almost certainly a more complete and rounded picture than any other source could provide. This paper does not explicitly explore change over time, but there appear to be few significant shifts in the nature and extent of pedestrianism over the nineteenth century, despite the changes in transport that occurred during this period. Travellers clearly used the expanding system of public transport in the form of omnibuses, trains (both surface and underground by the end of the century) and trams, but they also continued to walk both for an entire journey and for multi-mode trips.

The data are also largely descriptive: they tell us who walked, sometimes why they walked and some personal details. However, there is rarely enough information to fully explain the purposes and circumstances that led to a particular incident. What the data do show is that the streets of London were busy with pedestrians at most times of the day, evening and into the night; that women, men and children all walked, sometimes with companions but often alone; and that the streets accommodated people of all occupational classes from the likes of barristers and surgeons to labourers and domestic servants. In this sense the streets were a democratic space to which all had

${ }^{50}$. Witness statement by Henry Avory (police constable), $4^{\text {th }}$ February 1901. OB Ref: t19010204-176. 
access, and in which a wide range of people walked for a variety of purposes. ${ }^{51}$ However, the fact that rich and poor all walked the streets of London does not mean that they necessarily interacted with each other. Separation of residential and employment areas would mean that to some degree different people occupied distinct spaces, and it is possible to pass by someone on the pavement but to ignore their presence. The opportunities for interaction certainly occurred but the data usually do not indicate if interaction took place. However, as outlined above, it was often the case that a witness in a crowd on the pavement drew attention to a crime such as pickpocketing that had gone unnoticed at the time by the victim. It is also the case that often such instances involved pedestrians of different ages or social backgrounds. Such examples at least suggest that people were to some extent looking out for each other on the streets of nineteenth-century London, and that they were aware of the responsibilities that came with the use of this shared space.

To underline the above points I conclude with two further examples from witnesses of crimes. In both instances children who were on the street drew attention to a theft of personal property, and aided in the apprehension of a pickpocket. These interactions crossed generations and, so far as can be deduced, also often crossed social divides. The thefts observed could easily have been ignored by the children but, in these instances at least, they were not. The street may not have been a truly democratic space, but I suggest that there were elements of solidarity within the community of pedestrians that traversed the streets of London on a regular basis, and that this would have helped to make walking a comfortable and secure experience.

I am thirteen years old, and live in Mercers-row, Shadwell - my father goes out with vegetables. On the 4th of June I was going to the corn-chandler's, and saw the prisoner go behind the prosecutrix, at the bottom of Mercer's-row, knock her down, take off her shawl, and run up the court; I knew him before - he sits at the bottom of the street with apples and gooseberries. ${ }^{52}$

I was passing over Blackfriars-bridge. I saw the prisoner and two others following the prosecutor - I saw the prisoner put his hand into the pocket, then he took up the skirt of the coat, and

\footnotetext{
51 . For a broader discussion of the concept of democratic public space see S. Low and N. Smith, (eds.) The Politics of Public Space (New York, 2006); A. Cornwall and V. Schatten Coelho, (eds.), Spaces for Change?: The Politics of Citizen Participation in New Democratic Arenas (London, 2007). 52 . Witness statement by Frances Anderson (age 13), 30 th June 1831. OB Ref: t18310630-193.
} 
another man took the handkerchief out; he wiped his nose with it, and then went off directly - I told the prosecutor of it. ${ }^{53}$

${ }^{53}$. Witness statement by Henry Page (described as a 'boy'), 30 th June 1831. OB Ref: t18310630-96. 
Table 1: Summary characteristics of pedestrians in London, 1801-1911

\begin{tabular}{|c|c|c|c|c|c|c|}
\hline $\begin{array}{l}\text { Demographic } \\
\text { characteristics }\end{array}$ & & & & & & \\
\hline Male & Female & Adult & Child & & & Total \\
\hline $433(80.3)$ & 106 (19.7) & $503 \quad(93.3)$ & $\begin{array}{ll}36 & (6.7) \\
\end{array}$ & & & 539 \\
\hline \multicolumn{7}{|l|}{$\begin{array}{l}\text { Occupational } \\
\text { characteristics }\end{array}$} \\
\hline One & Two & Three & Four & Not stated & & Total \\
\hline $83(15.4)$ & 74 (13.7) & 97 (18.0) & 51 (9.5) & 234 (43.4) & & 539 \\
\hline \multicolumn{7}{|l|}{$\begin{array}{l}\text { Time of day } \\
\text { walking }\end{array}$} \\
\hline Morning & Afternoon & $\begin{array}{l}\text { Daytime } \\
\text { (unspecified) }\end{array}$ & Evening & Night & Not stated & Total \\
\hline $\begin{array}{ll}54 & (10.0)\end{array}$ & $114(21.2)$ & $30 \quad(5.6)$ & $224(41.6)$ & 89 (16.5) & $28(5.2)$ & 539 \\
\hline \multicolumn{7}{|l|}{$\begin{array}{l}\text { Walking } \\
\text { purpose }\end{array}$} \\
\hline Work & School & Errand & Leisure & Not stated & & Total \\
\hline 75 (13.9) & $4 \quad(0.7)$ & $29(5.4)$ & $271(50.3)$ & $160(29.7)$ & & 539 \\
\hline \multicolumn{7}{|l|}{$\begin{array}{l}\text { Number of } \\
\text { companions }\end{array}$} \\
\hline Alone & One & Two or more & & & & Total \\
\hline $373(69.2)$ & $125(23.2)$ & $41(7.6)$ & & & & 539 \\
\hline
\end{tabular}

Definition of occupational groups:

1: Professional and higher managerial/employer occupations including any with status and power in the community such as clergy and police.

2. Tradespeople/shopkeepers, dealers, clerks and other skilled non-manual occupations.

3. Skilled occupations in manufacturing and other industries.

4. Low skilled and unskilled occupations

Source: Old Bailey on-line - https://www.oldbaileyonline.org/ 
Table 2: Key characteristics of pedestrians by gender

\begin{tabular}{|c|c|c|}
\hline & Female & Male \\
\hline \multicolumn{3}{|l|}{ Time of day: } \\
\hline Morning & \begin{tabular}{|ll}
6 & $(5.7)$ \\
\end{tabular} & $48 \quad(11.1)$ \\
\hline Afternoon & $30 \quad(28.3)$ & $84 \quad(19.4)$ \\
\hline Daytime (not specified) & $\begin{array}{ll}6 & (5.7)\end{array}$ & $24 \quad(5.5)$ \\
\hline Evening & $50 \quad(47.2)$ & $174(40.2)$ \\
\hline Night & $9 \quad(8.5)$ & $80 \quad(18.5)$ \\
\hline Not specified & \begin{tabular}{|ll}
5 & $(4.7)$ \\
\end{tabular} & $23 \quad(5.3)$ \\
\hline \multicolumn{3}{|l|}{ Companions: } \\
\hline Alone & $60 \quad(56.6)$ & $313(72.3)$ \\
\hline One & $35 \quad(33.0)$ & $90 \quad(20.8)$ \\
\hline Two or more & $11(10.4)$ & $30 \quad(6.9)$ \\
\hline \multicolumn{3}{|l|}{ Journey purpose: } \\
\hline Work & $\begin{array}{ll}8 & (7.6) \\
\end{array}$ & $\begin{array}{ll}67 & (15.5)\end{array}$ \\
\hline School & $\begin{array}{ll}1 & (0.9) \\
\end{array}$ & $3 \quad(0.7)$ \\
\hline Errand & $17(16.0)$ & $12(2.8)$ \\
\hline Leisure & $47 \quad(44.3)$ & $224(51.7)$ \\
\hline Not specified & $\begin{array}{ll}33 & (31.1)\end{array}$ & $127(29.3)$ \\
\hline Total & 106 & 433 \\
\hline
\end{tabular}

Source: Old Bailey on-line - https://www.oldbaileyonline.org/ 
Table 3: Key characteristics of pedestrians by occupational group

\begin{tabular}{|c|c|c|c|c|c|}
\hline & 1 & 2 & 3 & 4 & NK \\
\hline \multicolumn{6}{|l|}{ Time of day: } \\
\hline Morning & $12(14.5)$ & 14 (18.9) & $4 \quad(4.1)$ & $\begin{array}{ll}4 & (7.8)\end{array}$ & $20(8.5)$ \\
\hline Afternoon & $16(19.3)$ & $\begin{array}{ll}12(16.2) \\
\end{array}$ & 11 (11.3) & 11 (21.6) & $\begin{array}{ll}64 & (27.4)\end{array}$ \\
\hline $\begin{array}{l}\text { Daytime (not } \\
\text { specified) }\end{array}$ & $\begin{array}{ll}6 & (7.2)\end{array}$ & $3 \quad(4.1)$ & $2 \quad(2.1)$ & $1 \quad(2.0)$ & $18(7.7)$ \\
\hline Evening & $33 \quad(39.8)$ & $27(36.5)$ & $47 \quad(48.5)$ & $24 \quad(47.1)$ & $93 \quad(39.7)$ \\
\hline Night & $15(18.1)$ & $13(17.6)$ & $32(33.0)$ & $\begin{array}{ll}7 & (13.7) \\
\end{array}$ & $22(9.4)$ \\
\hline Not specified & $\begin{array}{ll}1 & (1.2) \\
\end{array}$ & $\begin{array}{ll}5 & (6.8)\end{array}$ & $\begin{array}{ll}1 & (1.0) \\
\end{array}$ & $4 \quad(7.8)$ & $17(7.3)$ \\
\hline \multicolumn{6}{|l|}{ Companions: } \\
\hline Alone & $58 \quad(69.9)$ & $58(78.4)$ & $72(74.2)$ & 41 (80.4) & $144(61.5)$ \\
\hline One & $18 \quad(21.7)$ & $14(18.9)$ & $16(16.5)$ & $\begin{array}{ll}7 & (13.7) \\
\end{array}$ & $70 \quad(29.9)$ \\
\hline Two or more & $7 \quad(8.4)$ & $2 \quad(2.7)$ & $9 \quad(9.3)$ & $3 \quad(5.9)$ & $20 \quad(8.6)$ \\
\hline \multicolumn{6}{|l|}{$\begin{array}{l}\text { Journey } \\
\text { purpose: }\end{array}$} \\
\hline Work & $22(26.5)$ & 11 (14.9) & $\begin{array}{ll}8 & (8.3) \\
\end{array}$ & $13(25.5)$ & $21 \quad(9.0)$ \\
\hline School & $\begin{array}{ll}0 & (0.0)\end{array}$ & $\begin{array}{ll}0 & (0.0)\end{array}$ & $\begin{array}{ll}0 & (0.0)\end{array}$ & $\begin{array}{ll}0 & (0.0)\end{array}$ & $4 \quad(1.7)$ \\
\hline Errand & $\begin{array}{ll}2 & (2.4)\end{array}$ & $\begin{array}{ll}2 & (2.7)\end{array}$ & $4 \quad(4.1)$ & $\begin{array}{ll}1 & (2.0)\end{array}$ & $20 \quad(8.6)$ \\
\hline Leisure & $38 \quad(45.8)$ & 31 (41.9) & 68 (70.1) & $23(45.0)$ & $111(47.4)$ \\
\hline Not specified & $21(25.3)$ & $30 \quad(40.5)$ & 17 (17.5) & $14(27.5)$ & $78 \quad(33.3)$ \\
\hline Total & 83 & 74 & 97 & 51 & 234 \\
\hline
\end{tabular}

See Table 1 for definition of occupational groups.

Source: Old Bailey on-line - https://www.oldbaileyonline.org/ 